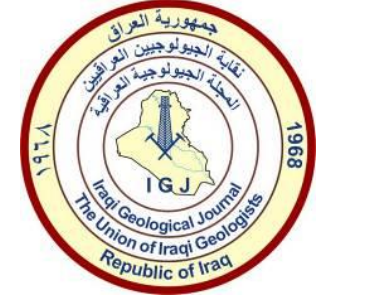

Iraqi Geological Journal

Journal homepage: https://www.igj-iraq.org

\title{
Environmental Evaluation of the Surface Water, Ground Water and Wastewater using Pollution Indices at the Landfill Site, Southern Baiji, Salah Al-Din, Northern Iraq
}

\author{
Sufian Mohammed Hammash ${ }^{1}$ and Mahmood Fadhil Abed ${ }^{1, *}$ \\ Department of Applied Geology, College of Science, Tikrit University, Tikrit, Iraq \\ Correspondence: env.geologist70@gmail.com
}

Received:
24 October 2021
Accepted:
30 November 2021
Published:
28 February 2022

\begin{abstract}
The current study aimed to assess the environmental risk of the municipal dump site on the quality of surface and groundwater in the city of Baiji in Salah al-Din Governorate, as 20 water samples were collected divided into three groups according to their type, 3 samples from the water of the Tigris River passing through the study area and 14 samples from water wells. Groundwater and 3 samples from the sewage drain passing through the study area. With regard to the concentrations of heavy metals, the results of the iron ion concentrations in the water samples of the Tigris River showed that they were within the permissible limit, while the percentage of 0.86 of the groundwater samples was within the permissible limit. Tigris and groundwater samples were within the permissible limit. The results of manganese and cobalt concentrations in all samples showed that they were above the permissible limit and the results of nickel concentrations in the Tigris River water samples showed that all of them were within the permissible limit, while the groundwater was 0.50 was within the permissible limit and 0.50 was above the permissible limit, while the concentrations of cadmium and zinc the device did not read them because their concentrations were below detection limit of the device. In terms of pollution of the Tigris River water and groundwater in the study area, the Heavy Metal Water Pollution Index showed that the Tigris River water samples were of medium pollution, as 0.78 of the groundwater samples were of low pollution and 0.22 of them were moderately polluted. Heavy metals results showed that the waters of the Tigris River were highly polluted, 0.78 of the groundwater samples were highly polluted, and 0.22 of them were moderately polluted and unfit for drinking according to the heavy metals assessment index. As for the degree of pollution index $(\mathrm{Cd})$, it showed that the water samples of the Tigris River were of a high degree of pollution and that 0.71 of the groundwater samples were of low pollution, 0.21 of them were highly polluted and one well of medium pollution.
\end{abstract}

Keywords: Pollution indices; Water quality; Heavy pollution index; landfill site

\section{Introduction}

Most developing countries suffer from the problem of municipal solid waste, as it is removed in an unscientific method and placed in open places, which causes a serious danger to the surrounding environment, as it is placed in low places and close to cities without abiding by the regulations and laws 
taken to protect the environment, as the location of the landfill affects the soil and on the quality of groundwater and thus affects the surface quality because of the landfill leachate, as hydrological factors such as rain precipitation, chemical weathering of minerals, topography of the landfill area and life interactions play a key role in filtering solid waste that results from human activities on the quality of groundwater. (Mishra et al., 2019). Since water quality is the product of a hydrochemical and environmental interaction between the four main environmental components (hydrosphere, lithosphere, gaseous envelope and biosphere) and that any pollution indicator that occurs in water quality is the result of a change in the composition of the natural ecosystem and its impact is reflected on human health, living organisms and the lack of plant productivity (Abdul Hafedh, 2019).The selection of a sanitary landfill site in developed and developing countries is affected by several geological and environmental factors that are taken into consideration when designing a sanitary landfill, including topography, site geology, site hydrogeology, soil type, land uses, slope, vegetation cover, fault areas and faults, as well as engineering, economic and legal requirements for building And the construction of sanitary waste dumps, as the inability to effectively manage this waste has become an issue of great importance because a number of solid waste contain toxic organic and inorganic pollutants (such as heavy metals) that threaten human health and the entire ecosystem, hence the need for a landfill. Sanitary Waste (Ireaja et al., 2018). Landfill leachate, which is a term used to express polluted and infiltrated water into the soil, surface and ground water, resulting from rainwater accompanied by dissolved and suspended municipal waste., which may contain potentially harmful substances (Warith, 2003), leachate can cause serious problems because it is capable of transporting pollutants that may contaminate soil, groundwater and surface water. Landfill gas, the primary gases that can be found in landfills include ammonia, carbon dioxide, methane, nitrogen and oxygen, produced from the decomposition of the organic part of municipal solid waste, methane and carbon dioxide are among the main landfill gases that are produced from waste components Biodegradable landfill organics (Ireaja et al., 2018). The aim of this study is to assess the environmental impact of the municipal landfill site on the surface and ground water southern of Baiji city using pollution indicators (Al-Hejuje, 2014). The researcher studied the evaluation of the Shatt al-Arab water and its impact on different water uses. He studied water pollution with heavy metals $(\mathrm{Ni}, \mathrm{Cd}, \mathrm{Cu}, \mathrm{Fe}, \mathrm{Mn}, \mathrm{Pb}, \mathrm{Zn}$ ), and the results showed that the concentration rate of $\mathrm{Pb}, \mathrm{Fe}$, and $\mathrm{Cd}$ metals exceeded the permissible limits. to the specifications of the World Health Organization (WHO) (Abed, 2016). The objective of the study is to assess the environmental risk of the industrial sector, which includes the North Refineries Company, the fertilizer company, the detergent factory, the heat and gas station on the waters of the Tigris River in the city of Baiji. The surface water showed no potential health risk to adults and children from consumers and workers, whether from drinking or from skin contact, except for bromine, which poses negative effects on digestion for children (Hussain and Abdulkader, 2017) The researchers studied the pollution of surface and ground water with heavy metals resulting from the waste of the Al-Quds Electricity Station, North of Baghdad, and it was found that the amount of danger resulting from digestion of all elements except zinc is less than 1 for adults and children and therefore does not pose a threat to public health, while the results of the risk index showed the risk of skin absorption of the two elements (Zinc and manganese) for children were more than 1 and thus pose a risk to the skin.

\section{The Location of the Study Area}

The study area is located between the coordinates (363966 - 362038) East and (3865151 to 3863408) North, its height ranges between 111-104 m above sea level and slopes towards the river, and the height of the river level in natural conditions is within the limits of 102.8-103.5 m above sea level, about $41 \mathrm{~km}$ away from Tikrit, the center of Salah Governorate. The area is bounded on the east by the Tigris River and the village of Al-Ba aiji, on the west by the main road (Baiji-Mosul), on the north by 
the city of Baiji, on the southeast by the village of Al-Malah, and on the south by the farm Fig. 1. The map of the study area showing on it the Tigris River, the sampling sites, the Baiji highway and the flood dam and adjacent sites.

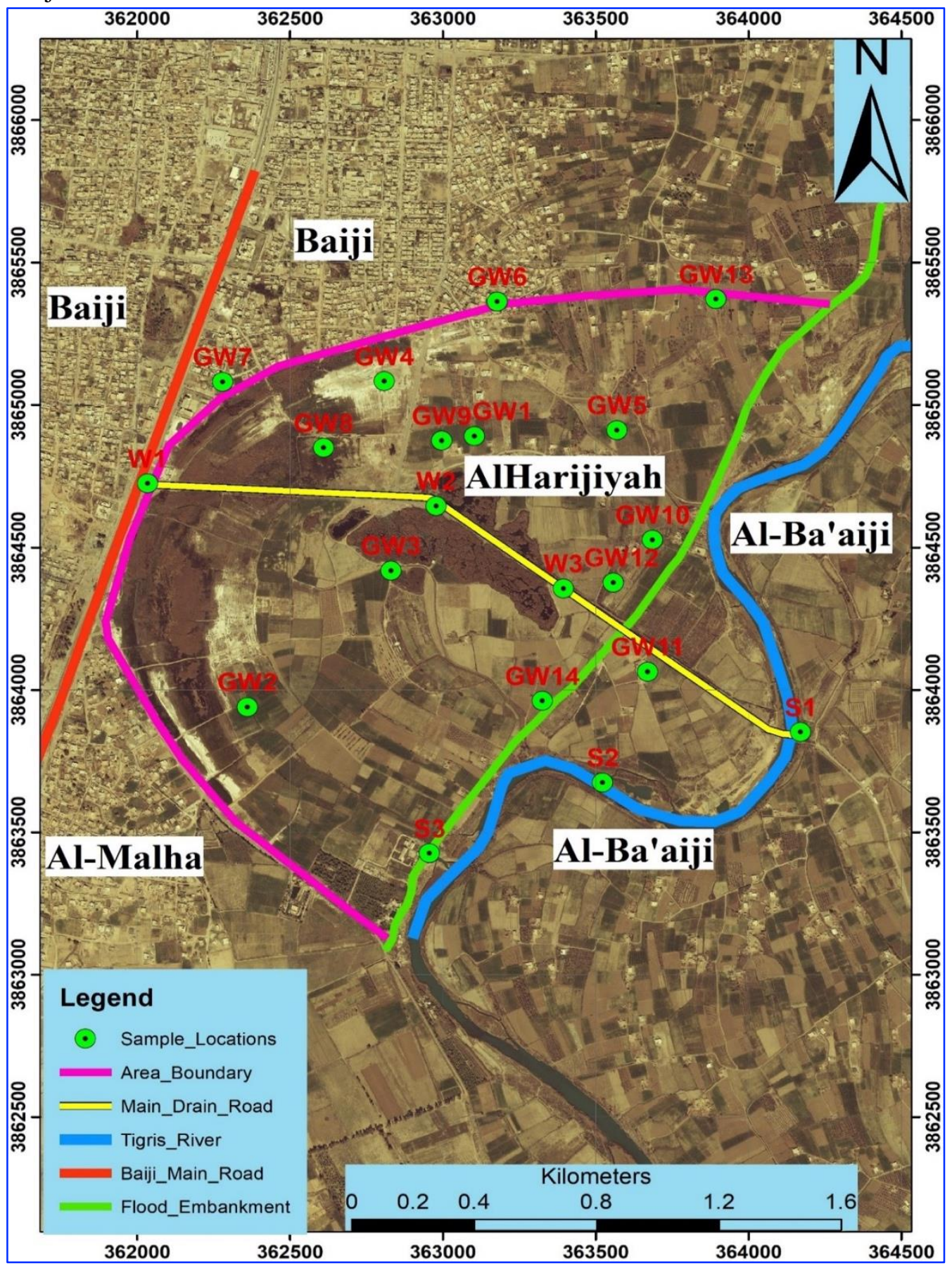

Fig. 1. The map of the study area

\section{Materials and Methods}

20 different water samples were collected in the study area, which included 14 samples of groundwater wells and their symbols (GW1, GW2 and GW14), 3 samples of surface water (Tigris River) and their symbols (S1, S2, S3) and 3 Wastewater samples and their symbols (W1, W2, W3). The concentrations of heavy metals (such as iron, copper, manganese, cobalt, nickel, cadmium and copper) were analyzed in the atomic absorption spectrometer, and then the equations for heavy metal pollution 
indicators (HPI), heavy metals assessment index (HMEI) and Contamination degree $\left(\mathrm{Cd}_{\mathrm{d}}\right)$ were applied. on the results of analysis of heavy metal concentrations (Table 1).

\section{Results}

\subsection{Pollution Indices}

\subsubsection{Heavy Metals Pollution Index (HPI)}

The heavy metal pollution index is an indicator that shows an estimate of the impact of each heavy metal on water quality in general (Reza and Singh, 2010). The heavy metal water pollution index, HPI, can be calculated in three steps according to Shankar (2019) as follows:

- Determine the weight of each heavy metal.

- Determine the values of the sub-indicators.

- The sum of the sub-indices for each heavy metal is calculated using the following equation:

$$
\mathrm{Wi}=\mathrm{k} / \mathrm{S}
$$

Where Wi: weight of the heavy metal, $\mathrm{k}=1$ : proportionality constant, $\mathrm{Si}$ : the permissible limit within the standards (WHO, 2017). The sub-indicators can be calculated using the following equation:

$$
Q i=\sum_{i=1}^{n} \frac{(M i-l i)}{(S i-l i)} \times 100
$$

The Qi is a sub-index for heavy metal.

Si: the permissible limit for a heavy metal.

Mi: The analyzed result for heavy metal in $\mathrm{mg} / \mathrm{L}$.

$\mathrm{Li}$ : The ideal value for a heavy metal.

$$
H P I=\sum_{i=1}^{n} Q i W i / \sum_{i=1}^{n} W i
$$

Wi: the weight of each heavy metal.

HPI is a heavy metal pollution index.

Table 1. Classification of heavy metal pollution index (HPI) according to Biswas et al. (2017)

\begin{tabular}{lc}
\hline Class & Level of pollution \\
\hline$<300$ & Low \\
$300_{-} 600$ & Medium \\
$>600$ & High \\
\hline
\end{tabular}

\subsubsection{Heavy Metal Evaluation Index (HMEI)}

The Heavy Metals Rating Index (HMEI) gives information about water quality for heavy metals, and the following equation is used to calculate the (HMEI) (Zakir et al., 2020).

$$
\mathrm{HMEI}=\sum_{i=1}^{n} H M_{\mathrm{Conc}} / \mathrm{HM}_{\mathrm{MPC}}
$$

Since HMcon is the measured concentration of a specific heavy metal, HMmpc is the internationally permissible concentration of a heavy metal. Water was classified according to the value of the heavy metals assessment index (HMEI) (Table 4). 
Table 2. The classification of water according to the value of HMEI

\begin{tabular}{lc}
\hline Level & HMEI \\
\hline Low & $<10$ \\
Medium & $10 \leq$ HMEI $\leq 20$ \\
High & $>20$ \\
\hline
\end{tabular}

\subsubsection{Contamination Degree $\left(C_{d}\right)$}

The pollution index (Cd) shows the relative pollution of different heavy metals separately. The index is calculated using the following equation (Backman et al. 1998)

$$
\begin{gathered}
\mathrm{C}_{\mathrm{d}}=\sum_{\mathrm{i}=1}^{\mathrm{n}} \mathrm{C}_{\mathrm{fi}} \\
\mathrm{Cfi}=\frac{C A i}{C N i}-1
\end{gathered}
$$

As Cfi is the pollution factor for metal i, CAi is the measured concentration of heavy metal i, CNi is the permissible concentration of heavy metal globally, and the water was classified according to the degree of pollution by (Biswas et al., 2017) (Table 3)

Table 3. Classification of water according to the degree of pollution $(\mathrm{Cd})$

\begin{tabular}{lc}
\hline $\mathbf{C}_{\mathbf{d}}$ & Contamination degree \\
\hline$<150$ & Low \\
$150_{-} 300$ & Medium \\
$>300^{-}$ & High \\
\hline
\end{tabular}

\begin{tabular}{|c|c|c|c|c|c|c|c|c|c|c|c|c|}
\hline Sample & Easting & Northing & $\begin{array}{c}\mathrm{Fe} \\
\mathrm{mg} / \mathrm{l}\end{array}$ & $\begin{array}{c}\mathrm{Cu} \\
\mathrm{mg} / 1\end{array}$ & $\begin{array}{l}\mathrm{Mn} \\
\mathrm{mg} / 1\end{array}$ & $\begin{array}{c}\mathrm{Co} \\
\mathrm{mg} / \mathrm{l}\end{array}$ & $\begin{array}{c}\mathrm{Ni} \\
\mathrm{mg} / \mathrm{l}\end{array}$ & $\begin{array}{c}\mathrm{Zn} \\
\mathrm{mg} / \mathrm{l}\end{array}$ & $\begin{array}{c}\mathrm{Cd} \\
\mathrm{mg} / \mathrm{l}\end{array}$ & HPI & HMEI & $\mathrm{Cd}$ \\
\hline W1 & 362035 & 3864725 & 0.19 & 8.42 & 0.9 & 0.027 & 0.004 & 0.402 & 0.002 & 382.24 & 21.47 & 427.71 \\
\hline W2 & 362979 & 3864646 & 0.04 & 7.83 & 0.96 & 0.023 & 0.005 & 0.654 & 0.04 & 354.95 & 31.6 & 346.1 \\
\hline W3 & 363396 & 3864356 & 0.54 & 7.66 & 1 & 0.058 & 0.008 & 0.835 & 0.088 & 366.15 & 66.9 & 365.78 \\
\hline S1 & 364171 & 3863852 & 0.01 & 0.1 & 0.7 & 0.034 & 0.002 & - & - & 213.76 & 18.87 & 363.33 \\
\hline S2 & 363524 & 3863675 & 0.01 & 0.08 & 0.9 & 0.032 & 0.004 & - & - & 247.65 & 18.4 & 416.05 \\
\hline S3 & 362957 & 3863426 & 0.02 & 0.04 & 0.6 & 0.031 & 0.002 & - & - & 199.53 & 17.13 & 94.88 \\
\hline GW1 & 363104 & 3864891 & 0.04 & 0.064 & 0.63 & 0.045 & 0.003 & - & - & 257.33 & 24.3 & 451.74 \\
\hline GW2 & 362362 & 3863940 & 0.03 & 0.06 & 0.58 & 0.039 & 0.006 & - & - & 224.76 & 23.87 & 99 \\
\hline GW3 & 362832 & 3864419 & 0.014 & 0.05 & 0.5 & 0.041 & 0.004 & - & - & 241.01 & 21.9 & 99.15 \\
\hline GW4 & 362809 & 3865084 & 0.028 & 0.046 & 0.54 & 0.057 & 0.007 & - & - & 347.81 & 30.11 & 99.41 \\
\hline GW5 & 363570 & 3864912 & 0.02 & 0.037 & 0.62 & 0.029 & 0.005 & - & - & 194.66 & 16.24 & 99.63 \\
\hline GW6 & 363179 & 3865364 & 0.02 & 0.058 & 0.48 & 0.036 & 0.008 & - & - & 204.04 & 19.46 & 94.62 \\
\hline GW7 & 362281 & 3865082 & 0.02 & 0.028 & 0.5 & 0.041 & 0.006 & - & - & 246.71 & 21.95 & 97.68 \\
\hline GW8 & 362611 & 3864850 & 0.018 & 0.039 & 0.57 & 0.052 & 0.005 & - & - & 316.75 & 20.89 & 99.31 \\
\hline GW9 & 362998 & 3864875 & 0.027 & 0.02 & 0.46 & 0.039 & 0.007 & - & - & 233.84 & 24.57 & 318.73 \\
\hline GW10 & 363687 & 3864527 & 0.016 & 0.04 & 0.55 & 0.046 & 0.006 & - & - & 276.08 & 24.57 & 297.59 \\
\hline GW11 & 363671 & 3864064 & 0.027 & 0.05 & 0.61 & 0.037 & 0.005 & - & - & 222.08 & 44.71 & 437.77 \\
\hline GW12 & 363559 & 3864377 & 0.031 & 0.067 & 0.63 & 0.029 & 0.003 & - & - & 186.63 & 16.27 & 99.52 \\
\hline GW13 & 363894 & 3865372 & 0.019 & 0.052 & 0.52 & 0.043 & 0.006 & - & - & 250.59 & 23.01 & 99.4 \\
\hline GW14 & 363326 & 3863961 & 0.023 & 0.017 & 0.47 & 0.039 & 0.003 & - & - & 382.24 & 20.82 & 99.42 \\
\hline
\end{tabular}

Table 4. Coordinates of sample sites and water tests and results of pollution indices

\section{Discussion}

The iron ion concentration ranges in the water models of the Tigris River and the two models (W1, W2) of wastewater and groundwater samples (GW2, GW3, GW4, GW5, GW6, GW7, GW8, GW9, GW10, GW11, GW13, GW14) within the permissible limits. The World Health Organization (WHO, 2017), while the two samples (GW1, GW2) had iron ion concentrations above the permissible limits due to the presence of iron oxide minerals in the sediments containing them in ground and surface 
waters. The concentration of copper in the waters of the Tigris River ranges between $0.1-0.031 \mathrm{mg} / \mathrm{liter}$ and at a rate of $0.073 \mathrm{mg} / \mathrm{liter}$, while its concentration in groundwater ranges between $0.1-0.017 \mathrm{mg} / \mathrm{liter}$ and at a rate of $0.024 \mathrm{mg} / \mathrm{liter}$, which is within the permissible limit of the World Health Organization (WHO, 2017) of $2 \mathrm{mg} /$ liter in the water samples of the Tigris River and groundwater samples, which are very low concentrations due to the presence of the sulfate ion in the region and the union of the copper ion with it or due to the adsorption processes on the surfaces of clay minerals in the study area (Al-Khalidi, 2008), while the wastewater samples were copper ion concentrations above the permissible limits (WHO, 2017). The concentration of manganese in the waters of the Tigris River ranges between $0.9-0.6 \mathrm{mg} / \mathrm{liter}$ and at a rate of $0.073 \mathrm{mg} / \mathrm{liter}$, while its concentration in groundwater ranges between $0.63-0.47 \mathrm{mg} / \mathrm{liter}$ and at a rate of $0.547 \mathrm{mg} / \mathrm{liter}$. The water models of the Tigris River and the groundwater and wastewater samples had manganese concentrations above the permissible limit (WHO, 2017) due to human activities and the study area was taken as a site for municipal waste dumping. The concentration of cobalt in the waters of the Tigris River ranges between 0.034_0.031 ppm while its concentration in groundwater is $0.057-0.029 \mathrm{ppm}$ at a rate of $0.041 \mathrm{mg} /$ liter. The concentration of nickel in the waters of the Tigris River ranges between 0.004-0.002 ppm, while its concentration in groundwater ranges between $0.008-0.003 \mathrm{ppm}$, which indicates that the water samples of the Tigris River, groundwater models and wastewater models were within the limits Allowed according to specifications (WHO, 2017). The Tigris River water models and groundwater samples did not show results for cadmium concentrations, which indicates that the cadmium concentrations in the Tigris River water models and groundwater models in the study area are less than the limits of detection by the Atomic Adsorbtion Spectrum, which is $10.00 \mathrm{mg} / \mathrm{L}$. The results of zinc concentration in the water samples of the Tigris River and groundwater models did not appear, which indicates that the concentrations of zinc in the water samples of the Tigris River and groundwater models in the study area are less than the detection limits of the atomic absorption spectrometer (which is $10.00 \mathrm{mg} / \mathrm{L}$ ).

The results of the heavy metal pollution index showed that the samples (W1, W2, W3, GW4, GW8, GW14) were moderately polluted, while the samples (S1, S2, S3, GW1, GW2, GW3, GW5, Gw6, GW7, GW9, GW10, GW12, GW13, GW14) were of low pollution according to the classification of Biswas et al. (2017), the values of the heavy metal pollution index in the Tigris River water samples, groundwater samples and wastewater samples. All results of the heavy metal assessment index showed that the samples (W1, W2, W3, GW1, GW2, GW3, GW4, GW7, GW8, GW9, GW10, GW11, GW13, GW14) were highly polluted, while the samples (S1, S2, S3, GW5, GW6, GW12) average pollution according to the classification of Zakir et al. (2020). The results of the degree of pollution showed that the samples (W1, W2, W3, S1, S2, GW1, GW9, GW10, GW11). ) were of a high degree of pollution, while the samples (S3, GW2, GW3, GW4, GW5, GW6, GW7, GW8, GW12, GW13, GW14) had a low degree of pollution according to the classification (Biswas et al., 2017).

The current location is not suitable as landfill. We recommend the local administration in the city of Baiji not to use the study area as a dumping ground because of its impact on the quality of ground and surface water and its various uses. Lining the sewage stream from its beginning to its downstream place in the Tigris River to ensure that sewage water does not infiltrate into the groundwater. Choosing a suitable site for dumping waste, taking into consideration all environmental, geological, engineering, climatic, economic and legal factors. Holding seminars that undertake to educate the local people to take care of the environment and to preserve the natural resources of surface and ground water, soil, rocks, minerals and vegetation cover and its impact on the health of the local population. The necessity of adhering to the legal legislation established to protect the environment. 


\section{Conclusions}

- Iron ion concentrations in the models were within the permissible limits of the World Health Organization in groundwater and the waters of the Tigris River, while the concentrations of copper were very few in the waters of the Tigris River and groundwater compared to what was permitted by the World Health Organization.

- The concentrations of manganese and cobalt ions in the waters of the Tigris River and groundwater in all models are above the permissible limits of the World Health Organization, while the nickel ion concentrations in all models were within the permissible limits of the World Health Organization.

- The concentrations of zinc and cadmium ions were very few and less than the detection limits of the device in the Tigris River water models and groundwater models in the study area, due to the fact that the basal $\mathrm{pH}$ values in the water of the Tigris River and groundwater, which helped to stabilize zinc and cadmium in their minerals, were not liberated into the water.

- By applying the HPI it was found that the waters of the Tigris River were of low pollution, while $78.5 \%$ of the groundwater samples were of low pollution and $21.5 \%$ were moderately polluted, while sewage water was moderately polluted.

- The HMEI showed that the wastewater and $66.3 \%$ of the Tigris River samples and $78 \%$ of the groundwater samples in the study area were highly polluted.

- The results showed that the highly polluted wastewater according to the contamination degree of pollution index $(\mathrm{Cd}), 66.3 \%$ of the Tigris River samples were highly polluted and $28.6 \%$ of the groundwater samples in the study area were highly polluted, while $71.4 \%$ of the water samples Underground low pollution and $.333 \%$. The water samples from the Tigris River were low in pollution.

\section{Acknowledgements}

The authors are very grateful to the reviewers, Editor in Chief Prof. Dr. Salih M. Awadh, the Secretary of Journal Mr. Samir R. Hijab, and the Technical Editors for their great efforts and valuable comments.

\section{References}

Abed, M. F., 2016. Environmental Risk Assessment of Industrial District, Baiji Area, Ph. D. Thesis, College of Science, University of Baghdad, Iraq.

Al-Hejuje, M. M., 2014. Application of Water Quality and Pollution Indices to Evaluate the Water and Sediments Status in the Middle Part of Shatt Al-Arab River, Ph. D. Thesis, Biology Department, College of Science, University of Basrah, 239pp.

Hussain, H. M., and Abdulkader, S. Z., 2017. Heavy metals pollution assessment of the water in Al-Quds Power plant in Baghdad. Iraqi Journal of Science, 58(3A), 1256-1261.

Abdul Hafedh, E. K., 2019. Hydrogeochemical and Environmental Evaluation of Drinking Water System in the Unified Tikrit Project, Salahaddin Governorate, Department of Applied Geology, College of Science. Tikrit University.

Backman, B., Bodis D., Lahermo, P., Rapant, S. and Tarvainen, T., 1998. Application of a groundwater contamination index in Finland and Slovakia, Environmental Geology, 36 (1), 55-64.

Biswas, P. K., Uddin, N., Alam, S., Sultana, S., \& Ahmed, T., 2017. Evaluation of heavy metal pollution indices in irrigation and drinking water systems of Barapukuria coal mine area, Bangladesh. American Journal of Water Resources, 5(5), 146-151.

Ireaja A. N., Okeke O. C. and Opara A. I., 2018. Sanitary Landfills: Geological and Environmental Factors that Influence Their Siting, Operation and Management, Department of Geosciences, Federal University of Technology, Owerri, Imo state, Nigeria. 
Mishra, S., Tiwary, D., Ohri, A., \& Agnihotri, A. K., 2019. Impact of municipal solid waste landfill leachate on groundwater quality in Varanasi, India. Groundwater for Sustainable Development, 9, 100230.

Reza, R., \& Singh, G., 2010. Heavy metal contamination and its indexing approach for river water. International Journal of Environmental Science \& Technology, 7(4), 785-792.

Shankar, B. S., 2019. A critical assay of heavy metal pollution index for the groundwaters of Peenya Industrial Area, Bangalore, India. Environmental Monitoring and Assessment, 191(5), 1-14.

Warith, M. A., 2003. Solid waste management: new trends in landfill design. Emirates Journal for Engineering Research, 8(1), 61-70.

WHO, 2017. Guidelines for Drinking Water Quality, Fourth Edition, 223-234.

Zakir, H., Sharmin, S., Arifa, A. and Shahinur, R., 2020. Assessment of health risk of heavy metals and water quality indices for irrigation and drinking suitability of waters: a case study of Jamalpur Sadar area, Bangladesh. Environmental Advances, 2, 100005. 